\title{
Fungi isolated in school buildings
}

\author{
ELŻBIETA EJDYS
}

Department of Mycology, University of Warmia and Mazury in Olsztyn

Oczapowskiego 1A, PL-10-719 Olsztyn-Kortowo, elzbieta.ejdys@uwm.edu.pl

Ejdys E.: Fungi isolated in school buildings. Acta Mycol. 42 (2):245-254, 2007.

The aim of the study was to determine the species composition of fungi occurring on wall surfaces and in the air in school buildings. Fungi isolated from the air using the sedimentation method and from the walls using the surface swab technique constituted the study material. Types of finish materials on wall surfaces were identified and used in the analysis. Samples were collected in selected areas in two schools: classrooms, corridors, men's toilets and women's toilets, cloakrooms, sports changing rooms and shower. Examinations were conducted in May 2005 after the heating season was over. Fungi were incubated on Czapek-Dox medium at three parallel temperatures: 25,37 and $40^{\circ} \mathrm{C}$, for at least three weeks.

A total of 379 isolates of fungi belonging to 32 genera of moulds, yeasts and yeast-like fungi were obtained from 321 samples in the school environment. The following genera were isolated most frequently: Aspergillus, Penicillium and Cladosporoium. Of the 72 determined species, Cladosporium herbarum, Aspergillus fumigatus and Penicillium chrysogenum occurred most frequently in the school buildings. Wall surfaces were characterised by an increased prevalence of mycobiota in comparison with the air in the buildings, with a slightly greater species diversity. A certain species specificity for rough and smooth wall surfaces was demonstrated. Fungi of the genera Cladosporium and Emericella with large spores adhered better to smooth surfaces while those of the genus Aspergillus with smaller conidia adhered better to rough surfaces. The application of three incubation temperatures helped provide a fuller picture of the mycobiota in the school environment.

Key words: fungi, school, walls, indoor air

\section{INTRODUCTION}

Schools belong to a specific category of public buildings were factors that increase the expansion of fungi belonging to different systematic and ecological groups accumulate. The technical condition of a school building which results from the construction technology, finish materials and its use significantly influences the occurrence of conditions favourable for a temporary or permanent occurrence of fungi (Bog a ck a 1997). School occupants constitute further sources or transmission vectors of fungi 
into and within a school building. The present author's previous studies show that fungi are isolated in over $1 / 3$ of school children (Ejdys 2003).

The bioaerosol in school buildings also consists of secondary metabolites produced by the mycobiota occurring in building partitions. Possible toxins penetrating the bodies of the children and school employees may cause various toxicoses (Budak 1998). On the other hand, antibiotics produced in low concentrations may induce resistance of the bacterial flora of school occupants (Markiewicz, Kwiatkowski 2001). As literature data on the diversity range of fungi in schools are greatly divergent (Levetin at al. 1995; Meklin at al. 2002; Dacarro et al. 2003), the species composition of fungi occurring on wall surfaces and in the air in school buildings was analysed.

\section{MATERIAL AND METHODS}

Fungi isolated from the air using the sedimentation method and from the walls using the surface swab technique were the study material. Types of finish materials on wall surfaces were identified and used in the analysis. Surfaces finished with acrylic or emulsion paint were defined as rough while the walls covered with gloss paint or tiled were defined as smooth. Macroscopic changes indicating the development of the mycelium were not found on the walls. Samples were collected in selected areas in two schools: classrooms, corridors, men's toilets and women's toilets, cloakrooms, sports changing rooms and shower (only school I). A total of $312 \mathrm{sam}$ ples were collected in 13 enclosed spaces within the school buildings. Studies were conducted in May 2005 after the heating season was over. Indoor temperature and air humidity were measured during sampling.

Fungi were incubated on Czapek-Dox medium at three parallel temperatures: 25,37 and $40^{\circ} \mathrm{C}$, for at least three weeks.

Cultured colonies of moulds were described macroscopically. Slides stained with cotton blue in lactophenol according to Gerlach (1972) were made to identify microscopic features. Biochemical properties were assessed using methods commonly accepted in mycological laboratories.

The obtained isolates of yeast-like fungi and yeasts were incubated on Sabouraud medium without antibiotics. Media containing antibiotics that could affect typical fungal features were not used (Dynowska 1991/1992). The isolates were incubated at $37^{\circ} \mathrm{C}$ for 48 hours. After fungal growth was obtained, the material was passed twice or three times onto fresh Sabouraud medium to eliminate bacteria which relatively often accompanied fungi in the first culture.

After pure bacteria-free strains were obtained, microcultures on Nickerson agar were established. Fungi were inoculated on glass slides, covered with a thin layer of the medium (ca. $2 \mathrm{~mm}$ ), and 2-3 drops of broth and serum in a ration of 1:1 were added onto the inoculation site. Microcultures were incubated at $37^{\circ} \mathrm{C}$ for 48 up to 72 hours.

Macroscopic features (size, colour, shape, texture, smell of the colony) and microscopic features (shape and size of budding cells, blastospores and chlamydospores, the diameter of pseudohyphae and hyphae) as well as biochemical features obtained on bio-Mérieux API-tests (API 20C, API 20C AUX) were used for identification. CHROMagar (bio-Mérieux) was used to differentiate individual species of the 
genus Candida. It was treated as an auxiliary test as it does not yield accurate results in mixed-species isolations (Bouchara et al. 1996). Photographic documentation was made throughout the process.

Yeast-like fungi and yeasts were determined using the following keys: Kregervan Rij (1984); Barnett, Payn and Yarrow (1990), and a study by Kurnatow sk a (1995). Fungi of the genera Aspergillus and Penicillium were identified up to the level of species using the following keys: Raper and Fennell (1965) and Raper, Thom and Fennell (1945). Other species were determined using the atlas of clinical fungi (de Hoog et al. 2000).

\section{RESULTS}

A total of 379 fungal isolates were obtained from 312 samples. 213 isolates were recorded in 7 study areas in school I and 166 isolates in school II. 32 genera of moulds, yeasts and yeast-like fungi were identified in the study material. Fungi of the genera Aspergillus, Penicillium and Cladosporium were isolated most frequently. Fungi belonging to 27 and 21 genera were recorded in school I and II, respectively; 16 genera occurred in the study areas in both buildings while the others were isolated only from one school and were usually sporadic isolates. 9 fungi of the genus Chaetomium and 4 of the genus Hormographiella were exceptionally recorded in school I (Fig. 1). Of the 72 fungal species identified in the samples, 33 species were isolated at least twice. A group of predominant species with a similar occurrence frequency can be distinguished. These are: Cladosporium herbarum (43 isolates$11.3 \%)$, Aspergillus fumigatus (39-10.3\%) and P. chrysogenum (37-9.8\%) as well as P. citrinum (32-8.4\%) (Tab. 1). P. chrysogenum (13.1\%), P. citrinum (11.7\%) and $\mathrm{Cl}$. herbarum (10.3\%) were isolated most frequently in school I. A. fumigatus occurred almost twice less frequently (6.6\%). It was, however, one of the species predominant in the mycobiota in school II, and its frequency of occurrence was $15.1 \%$. Cl. herbarum, whose prevalence was $12.7 \%$, was the second dominant. P. chrysogenum and P. citrinum, on the other hand, occurred with the frequency lower than $4.5 \%$. The differences in the species range in both buildings could also be noticed in the greater number of species belonging to the genus Aspergillus recorded in building I (18) than in building II (6).

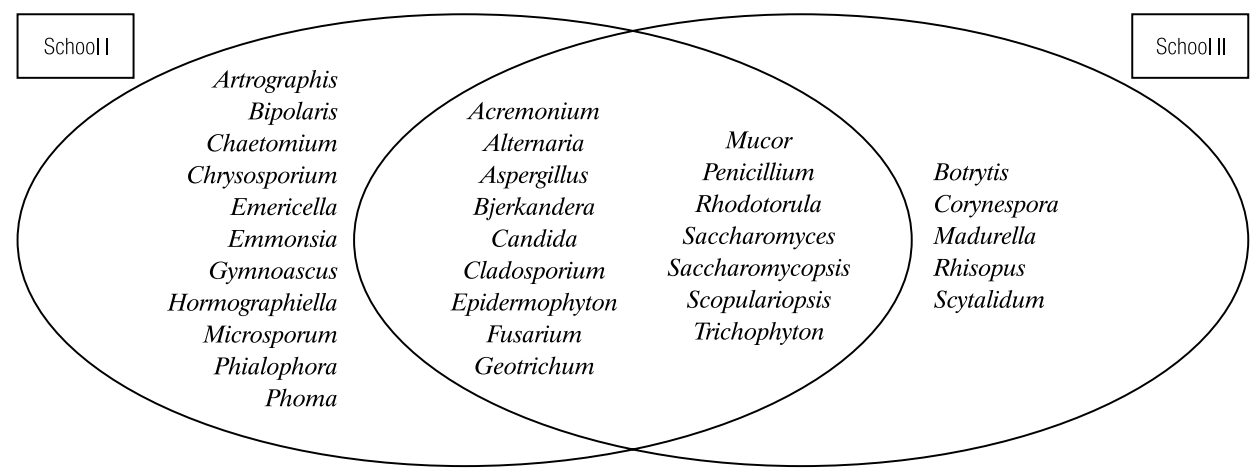

Fig.1. Occurrence of fungal genera in the school buildings. 


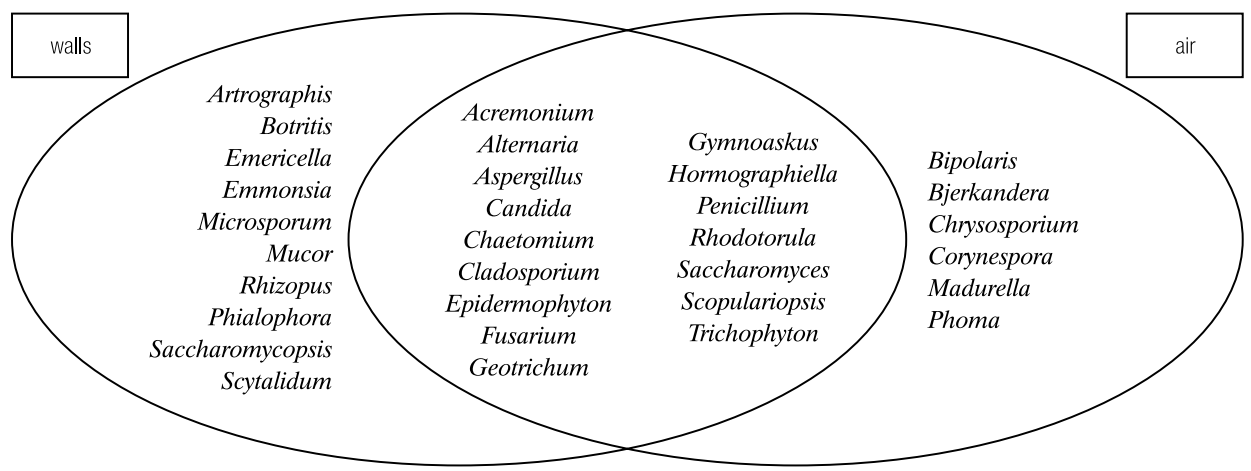

Fig. 2. Occurrence of fungal genera on the walls and in the air in the school buildings.

235 fungal isolates were obtained from the swabs and 144 isolates were obtained using the sedimentation method. 26 and 22 genera were recorded on wall surfaces and in the air, respectively; 16 genera were isolated in both sample types (Fig. 2). Only 6 genera were characteristic of the air. These were: Bipolaris, Bjerkandera, Chrysosporium, Corynespora, Madurella and Phoma. Fungi of the genera Penicillium (32 isolates), Cladosporium (26) and Aspergillus (22) were recorded most frequently in this medium. The same genera also dominated on wall surfaces although their stratification was slightly different. The genus Aspergillus unquestionably dominated (75 isolates). Yeast-like fungi, mostly of the genera Candida, Rhodotorula and Geotrichum, were frequently recorded in both sample types: $11.3 \%$. Significantly greater differences were recorded in the species range in the wall samples and the air samples. Twice as many species (65) were identified on the walls as in the air (32). However, the structure of the domination in both sample types was the same. 23 species common for both the walls and the air were recorded. Of the 32 species that occurred only on the surfaces in the school buildings, 16 species represented the genus Aspergillus. Only one isolate of the genus Candida, C. datilla, was determined from the air. The prevalence of yeast-like fungi in the air did not differ significantly from that on the wall surfaces and was $10.4 \%$ and $11.9 \%$, respectively. Fungi of the order Mucorales which occurred sporadically in the school buildings did not occur in the air at all.

A slightly smaller number of isolates was recorded on smooth walls (106) than on rough walls (129). Rough surfaces were characterised by a slightly greater species range (43 species) and a greater number of fungi belonging to the genus Aspergillus (15) than smooth walls ( 39 and 12 species, respectively). These differences were accompanied by an increased number of isolates of fungi of this genus: 45 on rough walls and 30 on smooth walls. The fungus Emericella quadrilineata was identified on the smooth wall in the sports shower, and its asexual stage, Aspergillus quadrilineatus, on the rough surface. However, a greater number of Cladosporium species were recorded on smooth surfaces. Apart from $\mathrm{Cl}$. herbarum, $\mathrm{Cl}$. cladosporoides, $\mathrm{Cl}$. oxysporum and $\mathrm{Cl}$. sphaerospermum also occurred. Significant differences in the species range and prevalence of fungi belonging to the genus Penicillium on both surfaces studied were not recorded. 
Table 1

Fungi isolated from the walls and the air in the school buildings

\begin{tabular}{|c|c|c|c|c|c|c|c|}
\hline \multirow[b]{2}{*}{ No } & \multirow[b]{2}{*}{ Fungal species } & \multicolumn{6}{|c|}{ Number of isolates } \\
\hline & & 吾 & 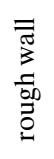 & 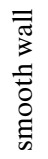 & $\exists$ & $\begin{array}{l}\overline{0} \\
\overline{0} \\
\bar{y} \\
n\end{array}$ & $\begin{array}{l}\Xi \\
\overline{8} \\
\frac{0}{0} \\
w\end{array}$ \\
\hline 1 & Acremonium alabamense Morgan-Jones & 1 & 1 & 0 & 0 & 1 & 0 \\
\hline 2 & Ac. hyalinulum (Sacc.) W. Gams & 1 & 0 & 1 & 0 & 1 & 0 \\
\hline 3 & Ac. kiliense Grütz & 1 & 0 & 1 & 0 & 0 & 1 \\
\hline 4 & Ac. roseogriseum (S.B. Saksena) W. Gams & 1 & 0 & 0 & 1 & 1 & 0 \\
\hline 5 & Acremonium sp. & 1 & 0 & 0 & 1 & 0 & 1 \\
\hline 6 & Alternaria alternata (Fr.) Keissl. & 2 & 1 & 0 & 1 & 0 & 2 \\
\hline 7 & A. infectoria Simmons & 1 & 0 & 1 & 0 & 1 & 0 \\
\hline 8 & Alternaria sp. & 2 & 2 & 0 & 0 & 0 & 2 \\
\hline 9 & $\begin{array}{l}\text { Artrographis kalrae (Tewari\&Macpherson) Singler } \\
\text { \& Carmichael }\end{array}$ & 1 & 0 & 1 & 0 & 1 & 0 \\
\hline 10 & Aspergillus allahabadi Mehrotra \& Agnihotri & 1 & 1 & 0 & 0 & 0 & 1 \\
\hline 11 & A. aureolus Fennell \& Raper & 1 & 0 & 1 & 0 & 1 & 0 \\
\hline 12 & A. auricomus (Gueguen) Saito & 1 & 0 & 1 & 0 & 1 & 0 \\
\hline 13 & A. caesiellus Saito & 5 & 3 & 2 & 0 & 1 & 4 \\
\hline 14 & A. candidus Link & 3 & 1 & 1 & 1 & 1 & 2 \\
\hline 15 & A. crystallinus Kwon \& Fennel & 1 & 1 & 0 & 0 & 1 & 0 \\
\hline 16 & A. flavus Link & 12 & 7 & 5 & 0 & 7 & 5 \\
\hline 17 & A. fumigatus Fresenius & 39 & 13 & 8 & 18 & 14 & 25 \\
\hline 18 & A. glaucus Link & 1 & 1 & 0 & 0 & 1 & 0 \\
\hline 19 & A. granulosus Raper \& Thom & 1 & 1 & 0 & 0 & 1 & 0 \\
\hline 20 & A. janus Raper \& Thom & 4 & 3 & 1 & 0 & 3 & 1 \\
\hline 21 & A. longobasidia (Bain.) Moseray & 1 & 0 & 1 & 0 & 1 & 0 \\
\hline 22 & A. malodoratus Kwon \& Fennell & 1 & 1 & 0 & 0 & 1 & 0 \\
\hline 23 & A. nidulans (Eidam) Wint & 1 & 0 & 1 & 0 & 1 & 0 \\
\hline 24 & A. niger Van Tieghem & 4 & 2 & 1 & 1 & 4 & 0 \\
\hline 25 & A. ochraceus Wilhelm & 1 & 1 & 0 & 0 & 1 & 0 \\
\hline 26 & A. quadrilineatus Thom \& Raper & 1 & 1 & 0 & 0 & 1 & 0 \\
\hline 27 & A. sydowi (Bain.\& Sart.) Thom \& Church & 3 & 0 & 3 & 0 & 3 & 0 \\
\hline 28 & A. versicolor Tiraboschi & 12 & 6 & 4 & 2 & 6 & 6 \\
\hline 29 & Aspergillus sp. & 4 & 3 & 1 & 0 & 1 & 3 \\
\hline 30 & Bipolaris spicifera (Bain.) Subram. & 2 & 0 & 0 & 2 & 2 & 0 \\
\hline 31 & Bjerkandera sp. & 4 & 0 & 0 & 4 & 2 & 2 \\
\hline 32 & Botrytis cinerea Pers. ex Pers. & 2 & 0 & 2 & 0 & 0 & 2 \\
\hline 33 & Candida albicans (Robin) Berkhout & 1 & 1 & 0 & 0 & 0 & 1 \\
\hline 34 & C. datila (Kluyver) S.A. Meyer \& Yarrow & 1 & 0 & 0 & 1 & 0 & 1 \\
\hline 35 & C. globosa Yarrow \& S.A. Meyer & 5 & 0 & 5 & 0 & 2 & 3 \\
\hline 36 & C. guilliermondii (Castellani) Berkhout & 1 & 1 & 0 & 0 & 0 & 1 \\
\hline 37 & C. krusei (Castellani) Berkhout & 1 & 1 & 0 & 0 & 0 & 1 \\
\hline 38 & $\begin{array}{l}\text { C. versatilis (Etchells \& T.A. Bell) S.A.Meyer \& } \\
\text { Yarrow }\end{array}$ & 2 & 0 & 2 & 0 & 2 & 0 \\
\hline
\end{tabular}


Tab. 1 cont.

\begin{tabular}{|c|c|c|c|c|c|c|c|}
\hline 39 & Chaetomium atrobruneum Ames & 9 & 3 & 5 & 1 & 9 & 0 \\
\hline 40 & Chrysosporium queenslandicum Apinis \& Rees & 1 & 0 & 0 & 1 & 1 & 0 \\
\hline 41 & Cladosporium cladosporoides (Fres.) de Vries & 3 & 2 & 0 & 1 & 3 & 0 \\
\hline 42 & Cl. herbarum (Pers.) Link: Fr. & 43 & 13 & 10 & 20 & 22 & 21 \\
\hline 43 & Cl. oxysporum Berk. \& Curt. & 3 & 1 & 0 & 2 & 0 & 3 \\
\hline 44 & Cl. sphaerospermum Penz. & 4 & 1 & 0 & 3 & 1 & 3 \\
\hline 45 & Corynespora cassiicola (Berk. \& Curt.) Wei & 1 & 0 & 0 & 1 & 0 & 1 \\
\hline 46 & $\begin{array}{l}\text { Emericella quadrilineata (Thom \& Raper) C.R. } \\
\text { Benjamin }\end{array}$ & 1 & 0 & 1 & 0 & 1 & 0 \\
\hline 47 & Emonsia crescens Emmons \& Jellison & 1 & 1 & 0 & 0 & 1 & 0 \\
\hline 48 & $\begin{array}{l}\text { Epidermophyton floccosum (Harz) } \\
\text { Langer. \& Milochevitch }\end{array}$ & 3 & 1 & 1 & 1 & 1 & 2 \\
\hline 49 & Fusarium incarnatum (Rob.) Sacc. & 3 & 1 & 1 & 1 & 1 & 2 \\
\hline 50 & Geotrichum candidum Link: Fr. & 9 & 2 & 4 & 3 & 3 & 6 \\
\hline 51 & G. clavatum de Hoog et al. & 4 & 0 & 1 & 3 & 4 & 0 \\
\hline 52 & Gymnoascus dancaliensis (Castell.) v. Arx & 2 & 1 & 0 & 1 & 2 & 0 \\
\hline 53 & Hormographiella aspregillata Guarro et al. & 2 & 1 & 0 & 1 & 2 & 0 \\
\hline 54 & H. verticillata Guarro et al. & 2 & 2 & 0 & 0 & 2 & 0 \\
\hline 55 & Madurella grisea MacKinnon et al. & 1 & 0 & 0 & 1 & 0 & 1 \\
\hline 56 & Microsporum fulvum Uriburu & 1 & 1 & 0 & 0 & 1 & 0 \\
\hline 57 & Mucor amphibiorum Schipper & 1 & 0 & 1 & 0 & 0 & 1 \\
\hline 58 & Mucor ramosissimus Samutsevich & 1 & 0 & 1 & 0 & 1 & 0 \\
\hline 59 & Penicillium camamberti Thom & 1 & 0 & 1 & 0 & 0 & 1 \\
\hline 60 & P. chrysogenum Thom & 37 & 12 & 10 & 15 & 28 & 9 \\
\hline 61 & P. citrinum Thom & 32 & 11 & 8 & 13 & 25 & 7 \\
\hline 62 & P. claviforme Bainier & 1 & 0 & 1 & 0 & 0 & 1 \\
\hline 63 & P. notatum Westling & 6 & 3 & 1 & 2 & 3 & 3 \\
\hline 64 & P. purpurrescens (Scopp) n. comb. & 1 & 1 & 0 & 0 & 1 & 0 \\
\hline 65 & P. steckii Zaleski & 4 & 0 & 2 & 2 & 0 & 4 \\
\hline 66 & Phialophora pubakii (Laxa) Schol-Schwarz & 1 & 1 & 0 & 0 & 1 & 0 \\
\hline 67 & Phoma cruris-hominis Punithalingam & 1 & 0 & 0 & 1 & 1 & 0 \\
\hline 68 & Rhizopus sp. & 1 & 1 & 0 & 0 & 0 & 1 \\
\hline 69 & Rhodotorula glutinis (Fresenius) F.C. Harrison & 12 & 3 & 2 & 7 & 8 & 4 \\
\hline 70 & Rhodotorula sp. & 5 & 3 & 2 & 7 & 4 & 1 \\
\hline 71 & Scopulariopsis brevicaulis (Sacc.) Bain. & 1 & 1 & 0 & 0 & 0 & 1 \\
\hline 72 & S. brumptii Salvanet-Duval & 3 & 0 & 1 & 2 & 1 & 2 \\
\hline 73 & S. flava (Sopp) Morton \& G. Smith & 2 & 1 & 1 & 0 & 2 & 0 \\
\hline 74 & Scopulariopsis sp. & 1 & 1 & 0 & 0 & 1 & 0 \\
\hline 75 & Saccharomyces cerevisiae Meyen ex E.C. Hansen & 5 & 2 & 1 & 2 & 2 & 3 \\
\hline 76 & Saccharomycopsis capsularis Schiönning & 2 & 2 & 0 & 0 & 1 & 1 \\
\hline 77 & Scytalidum lignicola Pesante & 1 & 0 & 1 & 0 & 0 & 1 \\
\hline 78 & Trichphyton tonsurans Malmsten & 1 & 0 & 0 & 1 & 1 & 0 \\
\hline 79 & T.verrucosum Bodin & 1 & 0 & 0 & 1 & 0 & 1 \\
\hline 80 & Trichophyton sp. & 4 & 0 & 4 & 0 & 4 & 0 \\
\hline \multirow[t]{2}{*}{81} & Unidentified isolates & 34 & 5 & 4 & 25 & 12 & 22 \\
\hline & Total & 379 & 129 & 106 & 144 & 213 & 166 \\
\hline
\end{tabular}


Humidity ranged between 43 and $49 \%$ in school I and between 48 and $52 \%$ in school II. These values correspond to the PN-ISO 8756: 2000 standard on the air quality. The temperature was quite low in school II and ranged from 17.0 to $18.6 \mathrm{C}^{\circ}$. It was warmer in school I, where the temperature ranged from 19.8 to $23.5 \mathrm{C}^{\circ}$.

\section{DISCUSSION}

The composition of indoor mycobiota may differ significantly due to the nature and physicochemical properties of specific indoor environments, their use and the number of occupants, also not excluding the time of exposure to fungi. Results of most mycological analyses show that so-called indoor fungi of the genera Aspergillus and Penicillium as well outdoor fungi, or "field fungi", such as Alternaria or Cladosporium, are recorded most frequently inside buildings (Levetin at al. 1995; Gut a row ska et al. 2004). In his analysis of the species range of indoor air in 19 groups of building facilities used for different purposes, Zys ka (2001) demonstrated 14 recurring species of the 227 identified fungi. In the present study, the occurrence of 7 species was confirmed: Alternaria alternata, Aspergillus flavus, A. fumigatus, A.niger, A.versicolor, Cladosporium herbarum, Penicillium chrysogenum. They include species dominant in the school buildings studied.

The range of fungal species that characterises indoor environment constitutes contamination of the pool of indoor fungi and species diffused with the air from outdoor environment (Bog a cka 1997). It is best visible in spring when after a long heating season increased ventilation begins without the need to prevent heat losses. Indoor temperature similar to that outdoors may also cause temporary enrichment of the mycobiota in buildings although there are usually fewer spores in the air in spring than in summer or autumn (Shelt on et al. 2002; To pbas et al. 2006). Thus, the great number of species isolated in the present study may indicate temporary contamination of the buildings by fungi from outside while those isolated only in the air may indicate incoming species. The greater taxonomic differentiation of the mycobiota in school I may result from its location in a park, with many trees and shrubs, some fountains, incorrectly performed drainage and, consequently, prolonged stagnation of rain waters. The latter may be of great importance in the context of the increase in air humidity which is one of the basic factors limiting the occurrence of moulds.

The age of the buildings is also an important factor encouraging contamination by fungi. Both schools are less than 30 years old and were constructed with prefabricated concrete. This should also be seen as one of the reasons for the high prevalence of fungi belonging to the genus Cladosporium which readily colonise cement surfaces (Ezeonu et al. 1994; Treau, Fernandes-Caldas 1994). Apart from the genus Cladosporium, fungi of the genera Penicillium, Aspergillus and Alternaria are often recorded in residential buildings (Gutarowski et al. 2004). The latter was rarely recorded in the present study. This may be related to the fact that spores of this fungus are isolated from the atmospheric air, and its occurrence indoors is connected with inappropriately used mineral wool in building insulation (Eze on u et al. 1994), the insulation method used in the schools studied.

Features that allow fungi to adhere quickly to the substrate or to occur in aerosols determine colonisation of indoor air or the retention of fungi in the air. This explains 
the significant species difference between the walls and the air reported in the literature (Gutarowska et al. 2004) and observed in the present study. The discrepancy is related more to the formation of the surface of the spores than to their size. According to Krzys zt ofik (1992), particles whose diameter ranges between 3 and 10 microns may remain in the air for long periods of time, even at very low upward air currents. The occurrence of large and smooth ascospores of Emericella quadrilineata on a smooth surface and only slightly smaller and rough conidia of its anamorph on a rough surface confirms these adaptations.

A relatively permanent occurrence frequency of yeast-like fungi accompanied the great differences in the prevalence of moulds in the wall samples and in the air samples. It seems that while species predominant in indoor environment are mostly correlated with the properties of the building itself, the presence of yeasts and yeastlike fungi is correlated more with living organisms occupying it. This is shown by a great species correspondence of fungi isolated across the four seasons of the year from buildings and their occupants, recorded by Macura and Gniadek (2003). Indoor prevalence of yeasts and yeast-like fungi shown by these authors $(10.7 \%)$ strictly corresponds to the present results. The occurrence of Saccharomycopsis capsularis, a fungus recorded only since the late 1990s in the respiratory system in adults (Dynowska, Biedunkiewicz 1999) and children (Ejdys 2003) in north-eastern Poland, was recorded in the school buildings studied.

The presence of yeast-like fungi is also affected by indoor humidity. Their occurrence is reported in the second place after that of the genus Penicillium in damp schools. Additionally, indicator fungi of water-damaged buildings were isolated in such places: Stachybotrys, Trichoderma and A.versicolor (Meklin at al. 2002). This tendency was confirmed in the present study. Only $10 \%$ prevalence of yeast-like fungi and $3 \%$ prevalence of A.versicolor were recorded at low air humidity in the schools.

The richness of indoor mycobiota also results from the parallel sample incubation at different temperatures. It was accepted that while the temperature range of fungi is very broad it consists of narrow ranges of individual species. Aspergillus fumigatus, a thermophilous fungus, with slow initial growth, may be an example. Although it can grow at room temperature, it may lose competition with other, more rapid-growing species characteristic of this temperature. The results of the present author's studies clearly show this. The domination of the genus Aspergillus similar to that observed in the school buildings was recorded in a significantly warmer climate in student halls in Egypt (Maghazy, Shaaban, El-Katatny 1996); it was, however, isolated rarely (Krawczyk, Kowalski, Ochęcka-Szymańska 1999) or was not isolated at all (Gutarowska at al. 2004) in flats in Poland, which is another argument in favour of the expansion of the range of incubation temperatures to achieve greater knowledge of the mycobiota of various buildings. 


\section{CONCLUSIONS}

1. A total of 379 fungal isolates belonging to 32 genera of moulds, yeasts and yeast-like fungi were obtained in the school environment. The following genera dominated: Aspergillus, Penicillium and Cladosporium.

2. Of the 72 fungal species determined, Cladosporium herbarum, Aspergillus fumigatus and Penicillium chrysogenum occurred most frequently in the school buildings.

3. Wall surfaces were characterised by an increased prevalence of mycobiota in comparison with the air in these buildings, with only slightly greater species diversity.

4. A certain species specificity for rough and smooth wall surfaces was shown. Fungi with large spores of the genera Cladosporium and Emericella adhered better to smooth surfaces while fungi with smaller conidia of the genus Aspergillus - to rough surfaces.

5. The application of three incubation temperatures helped determine a fuller range of fungi colonising the school buildings.

\section{REFERENCES}

Barnett J. A., Payne R., Yarrow D. 1990. Yeasts: Characteristics and identification. Cambridge Univ. Press.

Boga ck a E. 1997. Choroba budynków. Mikol. Lek. 4 (4): 233-237.

Bouchara J.P., Declerck P., Cimon B., Planchenault C., de Gentile L., Chabasse D. 1996. Routine use of CHROM agar Candida medium for presumptive identification of Candida yeast species and detection of mixed fungal populations. Clin Microbiol. Infect. 2 (3):202-208.

Budak A. 1998. Mikotoksyny. (In:) E. Baran (ed.) Zarys mikologii lekarskiej. Volumed, Wrocław.

Dacarro C., Picco A.M., Grisoli P., Rodolfi M. 2003. Determination of aerial microbiological contamination in scholastic sports environments. J. App. Microbiol. 95: 904-912.

DeHoog G.S., Guarro J., Gene J., Figueras M. J. 2000. Atlas of Clinical Fungi. Ed.2. Centraalbureall voor Schiielcultures/ Universitat Rovira i Virgili.

Dynowska M. 1991/1992. The influence of antibiotics on the morphology of Candida albicans and Candida stellatoidea. Acta Mycol. 27 (1): 205-211.

Dynowska M. 1995. Drożdże i grzyby drożdżopodobne jako czynniki patogenne oraz bioindykatory ekosystemów wodnych. Rozpr. hab. Studia i Materiały WSP 77, Olsztyn: 1-83.

Dynowska M., Biedunkiewicz A. 1999. Presence of Saccharomycopsis capsularis in the human respiratory system. Acta Mycol. 38 (1/2): 71-87.

Ejdys E. 2003. Fungal infection risk groups among school children. Acta Mycol. 34 (2): 281-287.

Ejdys E. 2003. Bioróżnorodność mikocenoz jamy ustnej, gardła i nosa dzieci w wieku 6-15 lat. Wiad. Parazyt. 49 (4): 363-374.

Ezeonu I.M., Price D.L., Simmons R.B., Crow S.A., Ahearn D.G. 1994. Fungal production of volatiles during growth on fibreglass. Appl. Environ. Microbiol., 60: 4172-4173.

Gerlach D. 1972. Zarys mikrotechniki botanicznej. PWRiL, Warszawa.

Gutarowska B., Piotrowska M., Żakowska Z., Wiszniewska M., Pałczyński C. 2004. Zanieczyszczenie grzybami strzępkowymi pomieszczeń mieszkalnych w Łodzi i ich wpływ na zdrowie użytkowników - badania wstępne. Mikotoksyny i patogenne pleśnie w środowisku. VII Międzynarodowa Konferencja Naukowa, Bydgoszcz: 214-220.

Krawczyk P., Kowalski M.L., Ochęcka-Szymańska A. 1999. Stężenie zarodników grzybów alergogennych w powietrzu mieszkań w Łodzi. Wiad. Parazyt. 45 (2): 255-262.

Kreger-van Rij N.J.W. 1984. The yeasts: a taxonomic study. Third revision and enlarged edition. Els Sci. Publ. B. V., Amsterdam. 
Kurnatowska A. 1995. Wybrane zagadnienia mikologii medycznej. Promedi, Łódź.

Krzyszt ofik B. 1992. Mikrobiologia powietrza. Wydawnictwo Politechniki Warszawskiej, Warszawa.

Levetin E., Shaughnessy R., Fisher E., Ligman B., Harrison J., Brennan T. 1995. Indoor air quality in schools: exposure to fungal allergens. Aerobiologia 11: 27-34.

Macura A.B., Gniadek A. 2003. Flora mikologiczna w środowisku Domu Pomocy społecznej im. Helclów w Krakowie w różnych porach roku. Mikol. Lek. 10 (3): 179-185.

Maghazy S.N., Shaaban G.M., El-Katatny M.S. 1996. Study of the dermatophytes in the students houses of Minia Universyty, Egipt. Acta Mycol. 31 (2): 191-197.

Markiewicz Z., Kwiatkowski Z.A. 2001. Bakterie, antybiotyki, lekooporność. Wydawnictwo Naukowe PWN, Warszawa.

Meklin T., Husman T., Vepsäläinen A., Vahteristo M., Koivisto J., Halla-Aho J., Hyvärinen A., Moschanderas D., Nevalainen A. 2002. Indoor air microbes and respiratory symptoms of children in moisture damaged and reference schools. Inoor Air 12:175-183.

Raper K.B., Fennell D.I. 1965. The genus Aspergillus. Wilians, Wilkins, Baltimore.

Raper K.B., Thom C., Fennell D.I. 1949. A manual of the Penicillia. Wilians, Wilkins, Baltimore.

Shelton B.G., Kirkland K.H., Flanders W.D., Morris G.K. 2002. Profiles of airborne fungi in buildings and outdoor environments in the United States. Appl. Environ. Microbiol. 68 (4): 17431753.

Topbas M., Tosun I., Can G., Kaklikkaya N., Aydin F. 2006. Identification and seasonal distribution of airborne fungi in urban outdoor air in an eastern Black Sea Turkish town. Turk. J. Med. Sci. 36:31-36.

Trude a u W., Fernandes-Cald as E. 1994. Identifying and measuring indoor air biologic agents. J. Allergy Clin. Immunol. 94 (2): 393-400.

Zyska B. 2001. Grzyby powietrza wewnętrznego w krajach europejskich. Mikol. Lek. 8 (3/4): 127-140.

\section{Grzyby izolowane z pomieszczeń szkolnych}

\section{Streszczenie}

Celem badań było określenie składu gatunkowego grzybów występujących na powierzchniach ścian i w powietrzu budynków szkolnych. Materiałem do badań były grzyby uzyskane z powietrza metodą sedymentacji i ze ścian techniką wymazu powierzchniowego, biorąc pod uwagę różne materiały wykończeniowe ścian. Próby pobierano z wybranych pomieszczeń dwóch szkół: sali lekcyjnej, korytarza, toalet damskiej i męskiej, szatni ogólnej, szatni sportowej oraz prysznica. Badanie przeprowadzono w maju 2005r., po zakończonym okresie grzewczym. Grzyby hodowano na podłożu Chapek-Doxa równolegle w trzech temperaturach: 25, 37 i $40^{\circ} \mathrm{C}$, przez co najmniej trzy tygodnie.

W środowisku szkolnym z 321 prób uzyskano 379 izolatów grzybów z 32 rodzajów grzybów pleśniowych, drożdży i grzybów drożdżopodobnych. Najczęściej izolowano rodzaje: Aspergillus, Penicillium i Cladosporium. Z oznaczonych 72 gatunków grzybów najczęściej w pomieszczeniach szkolnych występował: Cladosporium herbarum, Aspergillus fumigatus i Penicillium chrysogenum. Powierzchnie ścian charakteryzowały się zwiększoną prewalencją mikobioty w stosunku do powietrza tych pomieszczeń, przy nieco większej różnorodności gatunkowej. Wykazano pewną specyficzność gatunkową grzybów dla szorstkich i gładkich powierzchni ścian. Do powierzchni gładkich lepiej przylegały grzyby o dużych zarodnikach z rodzaju Cladosporium i Emericella, natomiast do szorstkich o mniejszych konidiach, z rodzaju Aspergillus. Zastosowanie trzech temperatur inkubacji pozwoliło na nakreślenie pełniejszego obrazu mikobioty środowiska szkolnego. 